\section{○前原 直樹}

\section{(財) 労働科学研究所}

小学校教師 S 氏(39 歳男性)の糖尿病の発症と進展 ・悪化の 様子とその間の職務ストレスの関係を同僚や児童・父母、妻 の証言や本人の作成書類などをもとに検討した。 89 年 5 月に はS 氏の尿糖は陰性であったが、6月に体重減少と侯の乾き を訴元、8月に糖尿病で入院。以降、食事に留意した生活を 送り、血糖コントロールも良好に推移していたが、 90 年 6 月 以降、再度悪化し始め(下表)、10/8脳梗塞を発症した。

90 年度のS 氏は、 5 年を担任し、学年主任的役割を果たし、 さらに保健体育委員会と体育主任に加え保健主事も兼衫てい た。これは、女性教師の比率が $80 \%$ と高く、男性が局代わり せざるを得なかったためである。担任学級は心身の要配慮児 童が多く(27/39名)、また、いじめや養護学級児童を抱えるな ぞ「子供だけで放っては掠けない」とS 氏が不安や检みをも らすほどのクラスであった。特に 5 月以降は, 父親の事件を 契機に再び不登校気味となった Fさんに特別な配慮が必要と なった。保健主事としては前年度に引き続き養護教諭と他の 教師の間の摩擦に対し、その調整役を果たしている。

7 月には期末処理に加え、プール管理 $(6 / 20-9 / 10)$ や体育会 準備など体育主任としての業務をほとんど一手にこなしてい る1泊 2 日の林間学校ではアレルギーなどでの要配慮児童 6 名の引率の他、全体行事の取り組み全てを指導している。こ の行事でも教師間の摩擦が再燃し、対応・調整に特別の苦慮 があった林間学校前後にはプール管理とPTAの水泳教室等 の指導で出勤している。また、10 月の全市の連合運動会で S 氏は組 立体操の責任者となったため、夏 休み中に精力的にプランを作って いる。

学校水泳が終わった後、9月 10 日からは連合運動会の朝練に参加 し、指導している。併行して体育 会の諸淮備が 22 日頃まで集中的

\begin{tabular}{|c|c|c|c|c|c|}
\hline 年 & 月 & 検查白 & 血糖 判定 & HbA1c & 判定 \\
\hline & 正常! & 筑再 & $70-120 \mathrm{mg} / \mathrm{de}$ & $4.1-6.0 \%$ & \\
\hline 89 & 5 & & 尿糖 $(-)$ & & \\
\hline & 6 & & & & $x$ \\
\hline & 7 & & & & $x$ \\
\hline & 8 & $8.7-8.7$ & $567 \times$ & 11 & $x$ \\
\hline & 9 & 9.13 & $122 \bigcirc$ & & \\
\hline & 10 & & & & \\
\hline & 11 & 11.2 & 93 (O) & & 0 \\
\hline & 12 & & & & 0 \\
\hline 90 & 1 & 1.17 & 1890 & 8.2 & 0 \\
\hline & 2 & 2.21 & $125 \bigcirc$ & 7.7 & 0 \\
\hline & 3 & 3.23 & 1300 & 7.4 & 0 \\
\hline & 4 & 4.25 & $83 \bigcirc$ & 7.6 & 0 \\
\hline & 5 & & & & \\
\hline & 6 & & & & $\Delta$ \\
\hline & 7 & & & & $\triangle$ \\
\hline & 8 & 8.08 & $331 \times$ & 8.9 & $\triangle$ \\
\hline & 9 & & & & $\triangle$ \\
\hline & 10 & 10.1 & $198 \triangle$ & 9.5 & $\Delta$ \\
\hline
\end{tabular}

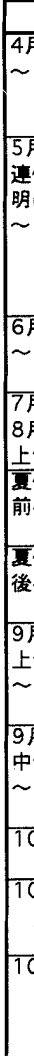

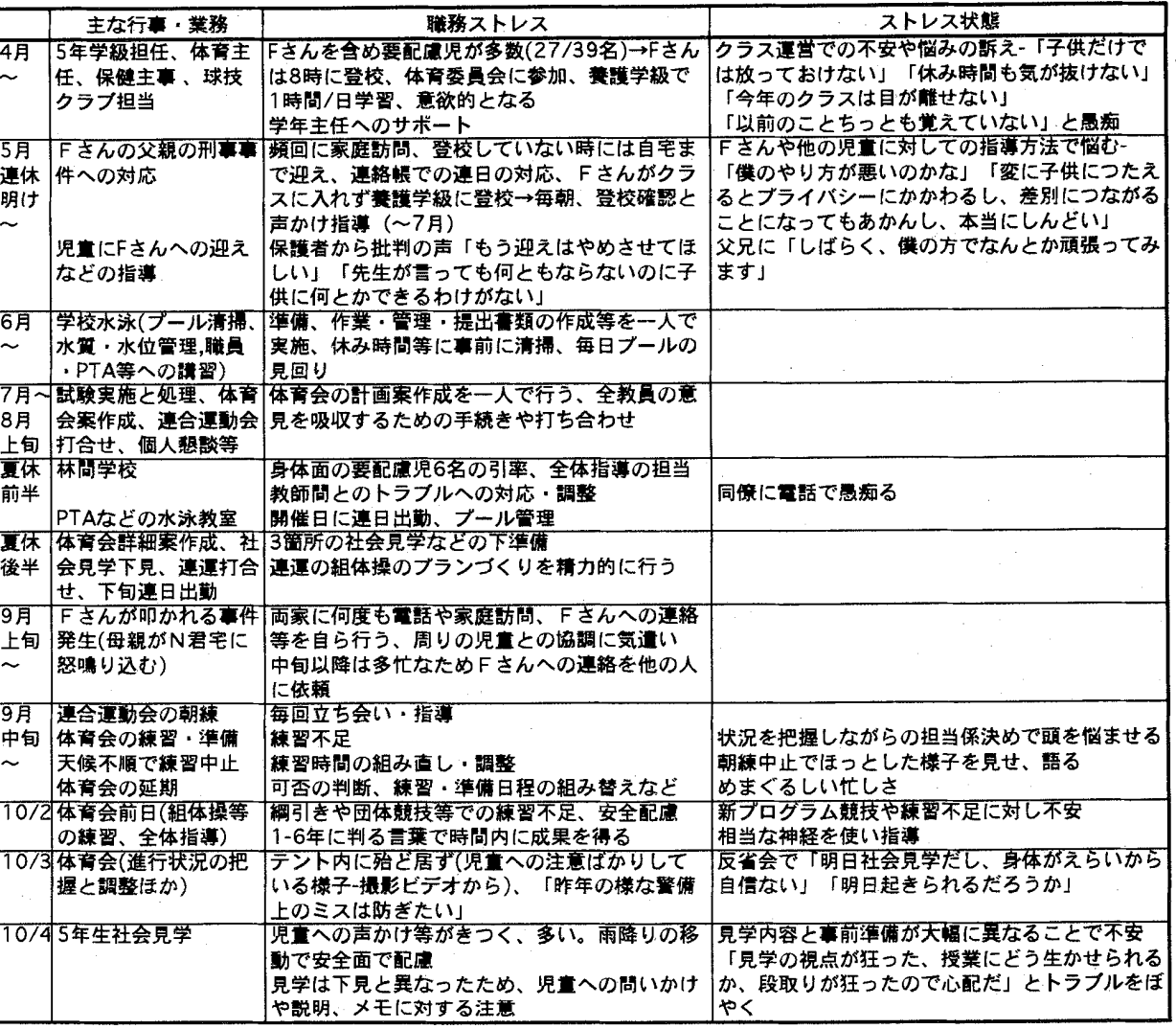

に行われたが、この間、脇の腫れ物で体調は良くはなかっ た。下旬にかけては早朝練習、学年や全体の練習、昼休み のリレーの指導や児童の淮備係の練習など体育会の練習 や準備が本格化したここの年は天候が不順で体育会の練習 は不足し、また準備変更等で体育主任としての業務は特段 に增していた。そのため休款時間や放課後を利用しての事 務処理等で多忙を極めた。これらに加え、9月初旬にはF さんが吒かれる事件が起き、収拾に苦慮している。何度も の家庭への連絡や訪問さらにFさんへの指導を S 氏自ら が行っている。また 9 月から不登校気味な児童の転入が加 わり、学級運営での困難さが特段に増していた。

下旬以降、過学が進行し、板書中のチョーク落下等の脳 梗塞の前駆症状も出現していた。台風で 30 日の体育会が 延期し、それに伴う業務も増し、一段と心身負担が増して いた。その様な中で $10 / 2,3$ の体育会の準備と本番、4 日の 社会見学が連続的になされた。体育会当日も全体の指導や 進行、ビデオや警備係等でテント内には殆どいない状態で あった。傍目にも判る位疲れ、顔色も悪くなっている。5 日の社会科見学では疲れや雨降りにより安全に特に注意 を払っている。工場内の見学ではロボットが稼衝していな い中、児童の興味を持続させる工夫が必要となった。

5 日の起床は「数回起こしてやっと起きてくる」状態と なり、日中も疲労困謈と脳梗塞の前駆症状が見られていた。 